\title{
Sorption equilibrium and kinetics of thin-layer drying of green bell peppers
}

\author{
Olga Reinert Ramos Gandolfi, Gabriel Ramos Ferreira Gonçalves, Renata Cristina Ferreira Bonomo, \\ Rafael da Costa Ilhéu Fontan*
}

Processes Engineering Laboratory, State University of Bahia Southwest, Itapetinga, Ba, Brazil

\section{A B S T R A C T}

Drying is a unit operation widely used in food preservation. It is important to know how this process takes place and the effects of variables such as temperature, relative humidity and air velocity. It is also essential to know the equilibrium moisture content of the product at the temperature under study. Thus, the objective of this study was to determine the sorption isotherms and evaluate the effects of temperature $\left(60^{\circ} \mathrm{C}\right.$ and $\left.75^{\circ} \mathrm{C}\right)$ and air velocity $\left(1.5 \mathrm{~m} \mathrm{~s}^{-1}\right.$ and $\left.3.0 \mathrm{~m} \mathrm{~s}^{-1}\right)$ on the thin-layer drying curves of green bell peppers. The experimental sorption data were adjusted to the BET and GAB models, where the latter best described the sorption behavior of the pepper. It was also verified that with the elevation in temperature lower values for the equilibrium moisture content were obtained. The drying data were adjusted to the Page model, Henderson and Pabis model, Newton model and Fick model. From the latter model the effective diffusion coefficient of water in the project was determined, confirming that the increase in temperature did not increase with greater air velocity. The Page model was that which best fit to all drying conditions. The variation in drying air velocity little affected the kinetics of the process, observing only a small reduction in drying time with increased air velocity (approximately $2.4 \%$ ), while temperature showed the greatest influence, with a large reduction in drying time with increase in this variable (around $41.4 \%$ ).

Keywords: Air velocity; Equilibrium moisture content; Mathematical modeling; Temperature; Tray dryer

\section{INTRODUCTION}

The bell pepper, Capsicum annum, is cultivated in temperate or tropical areas and is commonly consumed as a fresh vegetable, condiment or used for pharmaceutical purposes (Arslan and Özcan, 2011). This vegetable is highly perishable, requiring conservation techniques to maintain shelf life and quality (Singh et al., 2014).

To increase bell peppers conservation the drying operation is an alternative. This operation often involves the thermal energy transfer under controlled conditions using a heated air flow to remove, by evaporation, most of the water present in a food. The main objective was to increase the shelf life of products by reducing their water activity. Furthermore, it presents the additional advantage of reducing the volume and weight of products, diminishing storage and transportation costs (Vega-Gálvez et al., 2008).

To study the drying process of a food it is essential to know information about equilibrium conditions. This information is obtained in the form of moisture sorption isotherms, which describe the equilibrium relationship between food water content and environmental water activity encountered at a constant temperature (Pavan et al., 2012). Behavior of the isotherms could assume different shapes in function of the observed molecular interactions. Type II isotherms (sigmoidal) are the most common in moisture sorption equilibrium of foods (Andrade et al., 2011). Among the models used to describe the sorption isotherms for food, highlighted are the BET and GAB models (Kurozawa et al., 2015).

Liquid or vapor diffusion mechanism is the most important phenomena in drying processes, being the liquid diffusion theory based on Fick's second law the most utilized to describe them (Giraldo-Zuñiga et al., 2006).

The study of thin-layer drying kinetics is the most utilized in drying of foods. In this condition the air velocity, relative air humidity and temperature are considered constant when in contact with the food. Moreover, the temperature

\footnotetext{
*Corresponding author:

Rafael da Costa llhéu Fontan, Processes Engineering Laboratory, State University of Bahia Southwest, BR 415, km03, Itapetinga, BA, ZIP

45700-000, Brazil. E-mail: rafaelfontan@yahoo.com.br, rafaelfontan@uesb.edu.br
}

Received: 31 August 2017; Accepted: 29 January 2018 
variation along the material under study is quite low, being considered the effect only with time and not with position (Figueira et al., 2004). Many models applied to the thin layer drying are empirical, semi-empirical or simplification of the Fick's second law model. Among the most used are the Page model, Henderson and Pabis model, Newton model, Fick model, among others (Akpinar, 2006, Santos et al., 2010, Ertekin and Firat, 2017).

Therefore, the aim in this study was to determine the sorption isotherms and obtain the thin-layer drying curves of the green bell peppers at temperatures of $60^{\circ} \mathrm{C}$ and $75^{\circ} \mathrm{C}$ and different air flows, besides to evaluate the adjustment of the relevant models.

\section{MATERIALS AND METHODS}

\section{Acquisition and preparation of the samples}

The green bell pepper samples were obtained three times from the local market in the morning at Itapetinga city, Bahia State, Brazil, with size and degree of ripening uniform. Samples were washed in tap water to remove soil, sanitized by immersion in a solution containing $50 \mathrm{ppm}$ active chlorine for 30 minutes, followed by further washing under tap water. The peppers were then cut so as to obtained fine strips measuring roughly $0.04 \mathrm{~m}$ long, $0.005 \mathrm{~m}$ wide and $0.003 \mathrm{~m}$ thick.

\section{Determination of the sorption isotherms}

Moisture equilibrium of the samples in different conditions of water activity was determined at $60^{\circ} \mathrm{C}$ and $75^{\circ} \mathrm{C}$ using the static gravimetric method (Spiess and Wolf, 1993). Five saturated salt solutions were used for the widest possible range of water activities. The compounds used were sodium hydroxide $(\mathrm{NaOH})$, magnesium chloride $\left(\mathrm{MgCl}_{2}\right)$, sodium bromide $(\mathrm{NaBr})$, sodium nitrate $\left(\mathrm{NaNO}_{3}\right)$ and potassium chloride $(\mathrm{KCl})$. For saturated solution of $\mathrm{NaOH}$ the air relative humidity $(\mathrm{RH})$ was $3.61 \%$ at $60^{\circ} \mathrm{C}$ and $1.63 \%$ at $75^{\circ} \mathrm{C}$. For $\mathrm{MgCl}_{2}, \mathrm{NaBr}, \mathrm{NaNO}_{3}$ and $\mathrm{KCl}$ the $\mathrm{RH}$ were, in the order, respectively equal to $29.26 \%, 50.15 \%, 67.35 \%$ and $80.25 \%$ at $60^{\circ} \mathrm{C}$ and $26.94,49.70,65.56$ and $79.17 \%$ at $75^{\circ} \mathrm{C}$ (Greenspan, 1977).

To determine the adsorption isotherms an experiment with three repetitions was conducted in a completely randomized design. Thus, $3 \mathrm{~g}$ samples in quintuplicate were placed in stainless steel capsules and then stored in glass desiccators under vacuum in the presence of silica until complete removal of water, at a temperature of $60^{\circ} \mathrm{C}$. To determine the desorption isotherms, samples in natura were weighed in stainless steel capsules, also with three repetitions in quintuplicate and on the order of $3 \mathrm{~g}$. Samples for determination of the adsorption and desorption isotherms were then placed in desiccators containing the different saturated solutions of the compounds used. The desiccators were placed in thermally isolated boxes at temperatures of $60 \pm 2^{\circ} \mathrm{C}$ and $75 \pm 2{ }^{\circ} \mathrm{C}$. Samples remained in the desiccators until reaching the hygroscopic equilibrium, with insignificant variations in mass among weighings. The first weighing was performed after 7 days, and they were continued every two days until finding a constant weight between measurements. The equilibrium moisture content on a dry basis was then determined using Eq. (1), where the dry weight was obtained by drying in an oven at $105^{\circ} \mathrm{C}$ until constant mass (AOAC, 2016). Moisture content of the bell peppers in natura and the previously dehydrated samples for use in determination of the adsorption isotherms was also determined using the same method.

$$
M_{e}=\frac{m_{e q u i l i b r i u m-}-m_{d y}}{m_{d y}}
$$

Where: $M_{0}$ is the equilibrium moisture content on a dry basis - d.b. ( $\mathrm{g} \mathrm{H}_{2} \mathrm{O} / \mathrm{g}$ d.m.); $X_{m}$ is the equilibrium matter $(\mathrm{g})$; is the dry matter $-\mathrm{d} . \mathrm{m} .(\mathrm{g})$.

The experimental data of the sorption isotherms were adjusted to the GAB (Eq. (2) and BET models (Eq. (3)) (Figueira et al., 2004, Arslan and Togrul, 2005).

$$
\begin{aligned}
& M_{e}=\frac{\left(X_{m} C K A_{w}\right)}{\left(1-K A_{w}\right)\left(1-K A_{w}+C K A_{w}\right)} \\
& M_{e}=\frac{\left(X_{m} C A_{w}\right)}{\left(1-A_{w}\right)\left(1-A_{w}+C A_{w}\right)}
\end{aligned}
$$

Where: $M_{e}$ is the moisture content equilibrium - d.b. ( $g$ $\mathrm{H}_{2} \mathrm{O} / \mathrm{g}$ d.m.); $X_{m}$ is the monolayer moisture content in d.b. (dimensionless); $C$ is a parameter of the GAB and BET models (dimensionless); $A_{w}$ is the water activity (dimensionless) and $\mathrm{K}$ is a parameter of the GAB model (dimensionless).

Selection of the model that best explained the sorption behavior of the bell pepper was based on adjusting the parameters, the coefficient of determination $\left(\mathrm{R}^{2}\right)$ and the root mean square error (RMSE).

\section{Acquisition of the drying curves}

The drying process was performed in a tray dryer with gas heating (PD 150, Polidryer), regulated at the temperatures of $60^{\circ} \mathrm{C}$ and $75^{\circ} \mathrm{C}$ and with a parallel air flow equal to $0.0964 \mathrm{~m}^{3} \mathrm{~s}^{-1}$ (velocity of $1.5 \mathrm{~m} \mathrm{~s}^{-1}$ ) or $0.1927 \mathrm{~m}^{3} \mathrm{~s}^{-1}$ (velocity of $3 \mathrm{~m} \mathrm{~s}^{-1}$ ). The air velocity was adjusted by regulating the power of the dryer fan, where measurements were taken at the inlet of the machine 
using a portable digital anemometer (GM-816, Benetech, precision of $\left.0.1 \mathrm{~m} \mathrm{~s}^{-1}\right)$.

An initial loading density of $2.85 \mathrm{~kg} \mathrm{~m}^{-2}$ of bell peppers was used per tray. The trays were perforated rectangularshaped aluminum plates with dimensions of $0.35 \mathrm{~m} \times$ $0.30 \mathrm{~m}$. During the experiment, weighing was performed every 15 minutes until reaching constant weight on a semianalytical balance (BG4400, Gehaka, precision of $0.01 \mathrm{~g}$ ). After every weighing the trays were rotated by $90^{\circ}$ and relocated in the interior of the dryer to reduce experimental error. The initial and final moisture contents of the samples were determined via the gravimetric method, in an oven at $105^{\circ} \mathrm{C}$ until constant mass (AOAC, 2016).

The experiment was conducted in a completely randomized design (CRD) with two repetitions in triplicate. The room temperature was near $25 \pm 2^{\circ} \mathrm{C}$ and the relative humidity before heating was about $59 \%$. The relative humidity of the air drying was $9.4 \%$ at $60^{\circ} \mathrm{C}$ and $4.9 \%$ at $75^{\circ} \mathrm{C}$. To the drying data were adjusted the Henderson and Pabis model, Newton model, Page model and Fick model, shown in Eqs (4) - (7), respectively (Santos et al., 2010, Ertekin and Firat, 2017). Adjust of the parameters; the coefficient of determination $\left(\mathrm{R}^{2}\right)$ and the root mean square error (RMSE) were used to select the model that best described the drying kinetics in question. The Fick Model was truncated at the second term to determine the diffusion coefficient.

$$
\begin{aligned}
& M R=\operatorname{Cexp}^{-k t} \\
& M R=\exp ^{-k t} \\
& M R=\exp ^{-k t^{n}} \\
& M R=\frac{8}{\pi^{2}} \sum_{n=0}^{\infty} \frac{1}{(2 n+1)^{2}} \exp \left[-\frac{(2 n+1)^{2} \pi^{2} D t}{4 L^{2}}\right]
\end{aligned}
$$

where: $M R$ is the moisture ratio (dimensionless), $t$ is the drying time ( $\mathrm{min}), k, n$ and $C$ are parameters of the models, $D$ is the effective diffusion coefficient of the water $\left(\mathrm{m}^{2} \mathrm{~min}^{-1}\right)$ and $\mathrm{L}$ is the characteristic dimension of the bell pepper (m).

The moisture ratio was calculated according to Equation 8:

$$
M R=\frac{M-M_{e}}{M_{0}-M_{e}}
$$

where: $M R$ is the moisture ratio (dimensionless); $M$ is the moisture content - d.b. at time $\mathrm{t}(\mathrm{min}) ; M_{e}$ is the moisture content equilibrium - d.b. $\left(\mathrm{g} \mathrm{H}_{2} \mathrm{O} / \mathrm{g}\right.$ d.m.) and $M_{0}$ is the initial moisture content - d.b ( $\left(\mathrm{g} \mathrm{H}_{2} \mathrm{O} / \mathrm{g}\right.$ d.m.).

\section{RESULTS AND DISCUSSION}

\section{Sorption isotherms}

Experimental results for the equilibrium moisture content of the green bell peppers in function of water activity at the temperatures of $60^{\circ} \mathrm{C}$ and $75^{\circ} \mathrm{C}$ are presented in Fig. 1.

It was verified that the equilibrium moisture content increased with higher water activity values. With respect to increasing temperature, there was a decrease in equilibrium moisture content, indicating that the bell pepper became less hygroscopic. This behavior is in agreement with the findings of Arévalo-Pinedo et al. (2004) for murici pulp, and this trend can be explained by considering the excitation state of the molecules. At higher temperatures the molecules are found in a high degree of excitement, increasing the distance between them and thus reducing attractive forces. This fact leads to a decrease in the degree of water absorption at a given water activity with increase in temperature (Arslan and Togrul, 2005).

According to Palipane and Driscoll (1993), the increase in temperature causes water molecules to achieve higher energy levels, making them less thermodynamically stable. This allows that the bond is ruptured between water and the sorption sites, reducing the water content of the food. The effect of temperature on sorption isotherms is of great importance, since foods are exposed to various temperatures during storage and processing, thereby leading to changes in their water activity (Arslan and Togrul, 2005).

It was also observed in the Fig. 1 that the equilibrium moisture values in the desorption process are greater than in the adsorption process at both temperatures, thus demonstrating the hysteresis phenomenon. Similar behavior was observed by Yan et al. (2008), who studied the sorption isotherms of banana. According to Arslan and Togrul (2005), this phenomenon is due to the irreversible process and structural and physico-chemical changes that occur in the material during dehydration. When the samples are dried for performing the adsorption experiments there occurs a rearrangement so that the sorption sites are reduced, resulting in reduction of the water bonding capacity when the product is humidified again in the adsorption process.

Table 1 shows the parameters of the models fit to the experimental data obtained in the adsorption and desorption processes at the different temperatures studied, as well as their respective coefficients of $\mathrm{R}^{2}$ and RMSE values.

It was observed that values of the monolayer moisture content $\left(X_{m}\right)$ and content constant $C$ of the GAB and 


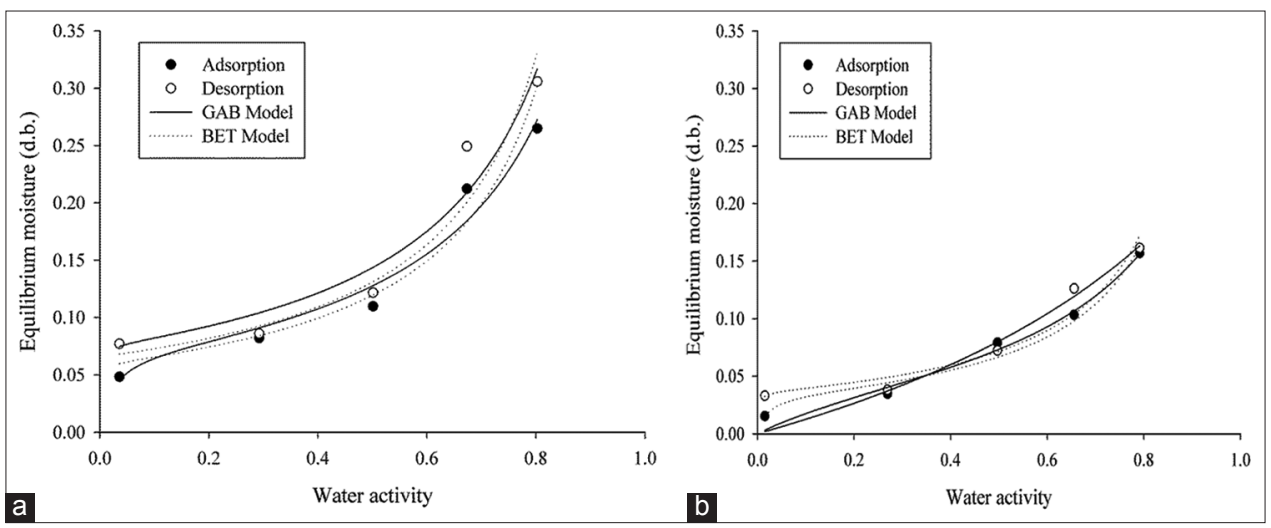

Fig 1. Experimental data and models adjusted to the sorption equilibrium. (a) $60^{\circ} \mathrm{C}$ and (b) $75^{\circ} \mathrm{C}$. (•) data for adsorption and (०) data for desorption.

Table 1: Fitted parameters, coefficient of determination $\left(\mathbf{R}^{2}\right)$ and RMSE of the equilibrium sorption models evaluated.

\begin{tabular}{|c|c|c|c|c|c|}
\hline \multirow[t]{2}{*}{ Model } & \multirow[t]{2}{*}{ Parameter } & \multicolumn{2}{|c|}{ Adsorption } & \multicolumn{2}{|c|}{ Desorption } \\
\hline & & $60^{\circ} \mathrm{C}$ & $75^{\circ} \mathrm{C}$ & $60^{\circ} \mathrm{C}$ & $75^{\circ} \mathrm{C}$ \\
\hline \multirow[t]{5}{*}{ GAB } & $\mathrm{Xm}(-)$ & 0.0699 & 0.0448 & 0.0754 & 0.0112 \\
\hline & C (-) & 48.7105 & 5.3487 & 606.5461 & 2.0167 \\
\hline & K (-) & 0.9287 & 0.9153 & 0.9497 & 0.7140 \\
\hline & $\mathrm{R}^{2}$ & 0.9813 & 0.9950 & 0.9705 & 0.9807 \\
\hline & RMSE & 0.0158 & 0.0058 & 0.0226 & 0.0139 \\
\hline \multirow[t]{4}{*}{ BET } & $\mathrm{Xm}(-)$ & 0.0568 & 0.0352 & 0.0655 & 0.0370 \\
\hline & C (-) & 147.3512 & 9.8004 & 173055.1276 & 385.9091 \\
\hline & $\mathrm{R}^{2}$ & 0.9715 & 0.9925 & 0.9637 & 0.9759 \\
\hline & RMSE & 0.0202 & 0.0060 & 0.0255 & 0.0113 \\
\hline
\end{tabular}

BET models decreased with increasing temperature. This temperature dependence was also observed by Goula et al. (2008) and Perdomo et al. (2009). The decrease in $X_{m}$ was attributed to diminution in the number of active sites due to physical and chemical changes induced by temperature.

The value of $X_{m}$ the parameter obtained for the BET and GAB models is of particular interest, since it indicates the amount of water that is strongly adsorbed on the specific sites of the food surface and is considered the optimum value to ensure stability. From the value of the monolayer it is possible to correlate the beginning of a series of chemical reactions related to food spoilage, since it was at this point that free water was found, which is available as a solvent and enables microorganism multiplication and the occurrence of chemical and enzymatic reactions (Comunian et al., 2011).

For the temperatures evaluated the parameters $\mathrm{C}$ and $\mathrm{K}$ presented values greater than 2 and less than 1 , respectively, which is in accordance with Blahovec (2004) who reported that these values are characteristic of type II isotherms. The sorption isotherms obtained for the green bell pepper presented sigmoidal shape (type II) and according to Arslan and Togrul (2005) this is the isotherm type found for most food products.
It can also be observed in Table 1 that the two models used showed coefficient of determination values greater than 0.95 and RMSE below 0.03, well representing the sorption isotherms in green bell peppers at the temperatures studied. The GAB model was selected because it presented the lowest RMSE and highest $\mathrm{R}^{2}$, thus showing better agreement with the phenomenon studied.

\section{Drying curves}

Figs. 2 and 3 show the experimental results of the thin-layer drying curves of the green bell peppers, at temperatures of $60^{\circ} \mathrm{C}$ and $75^{\circ} \mathrm{C}$, and velocities of $1.5 \mathrm{~m} \mathrm{~s}^{-1}$ and $3 \mathrm{~m} \mathrm{~s}^{-1}$, as well as the fitted models.

It was observed that in all cases studied, the moisture ratio decreased rapidly at the beginning of the process, where its decrease was slower as the drying process evolved and the moisture remaining in the product was reduced. Similar behavior was founded by several authors in literature, such as Vega et al. (2007) who studied the drying of red peppers and Doymaz (2008) who studied strawberry drying kinetics.

It was observed that the air velocity for the conditions studied little affected the drying kinetics of the green bell pepper, considering that for the two temperatures studied, when varying the velocity the drying times were similar. For the temperature of $60^{\circ} \mathrm{C}$ and velocity of $1.5 \mathrm{~m} \mathrm{~s}^{-1}$ the 


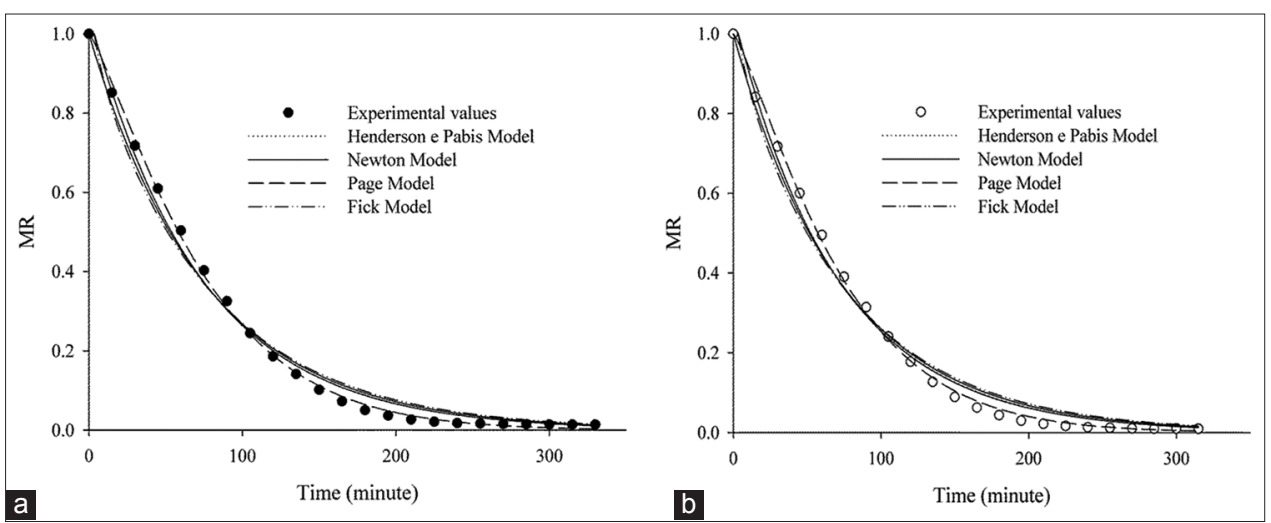

Fig 2. Experimental and predicted data for thin-layer drying of the green bell peppers at $60^{\circ} \mathrm{C}$ with air velocities of $1.5 \mathrm{~m} \mathrm{~s}^{-1}(\mathrm{a})$ and $3.0 \mathrm{~m} \mathrm{~s}^{-1}(\mathrm{~b})$.

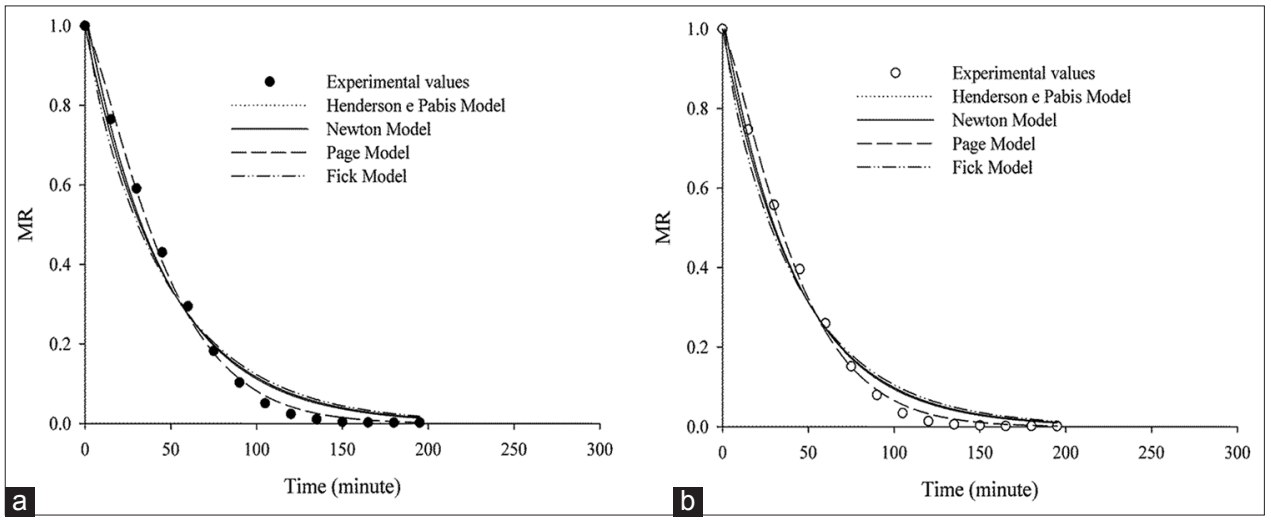

Fig 3. Experimental and predicted data for thin-layer drying of the green bell pepper at $75^{\circ} \mathrm{C}$ with air velocities of $3.0 \mathrm{~m} \mathrm{~s}^{-1}(\mathrm{a})$ and $1.5 \mathrm{~m} \mathrm{~s}^{-1}(\mathrm{~b})$.

total drying time was 330 minutes, while for the speed of $3 \mathrm{~m} \mathrm{~s}^{-1}$ the total drying time observed was 315 minutes, where in both cases there was a tendency to stabilize the moisture ratio at the same time ( $\sim 225$ minutes). For the temperature of $75^{\circ} \mathrm{C}$ at both velocities the drying time was similar ( $\sim 195$ minutes), tending to stabilize the moisture ratio after approximately 120 minutes. This fact is in agreement with the findings of Krokida et al. (2003), who reported that the drying air velocity, between $1.5 \mathrm{~m} \mathrm{~s}^{-1}$ and $2.6 \mathrm{~m} \mathrm{~s}^{-1}$, did not significantly affect the drying kinetics of numerous plants, therefore being a variable of minor importance in the process.

It was also verified that the increase in drying air temperature resulted in a greater water removal rate from the bell pepper at the beginning of the process. For the temperature of $60^{\circ} \mathrm{C}$ the minimum drying time observed was 315 minutes for the air velocity of $3 \mathrm{~m} \mathrm{~s}^{-1}$, while at $75^{\circ} \mathrm{C}$ the drying time for the two velocities studied was 195 minutes. These results are in accordance with those observed by GiraldoZuñiga et al. (2006) for jackfruit and Santos et al. (2010) for carambola, who observed that temperature is a variable that has a great influence on the process.

Values of the adjusted parameters of the tested models are shown in Table 2 and corroborated with the observations made previously. Little variation was observed in the drying constant, $k$, for the different air velocities tested, indicating that this variable had a smaller effect on the drying process, while for temperature a greater variation in the value of $k$ was observed, showing a greater effect of this variable. It is known that the larger the $k$ value the shorter the total drying time.

It was verified that all the models tested showed high values for the coefficient of determination and low RMSE, satisfactorily adjusting to the experimental data and well representing the drying kinetics of green bell peppers. The Page model presented the best fit to the experimental data for bell pepper drying, and therefore presented a better description of the drying process in all cases studied. In addition, the Page model has only two parameters, which makes its use simpler and more common when its fitting is satisfactory.

From adjustment of the Fick model values were obtained for the effective diffusion coefficient of water in the product. The values obtained for the two drying air velocities at the same temperature were fairly close. It was expected, once different velocities should be important mainly in convective aspects of drying. However, when comparing the effective diffusion value of water between temperatures there was a greater difference, indicating that 
Table 2: Fitted parameters, coefficient of determination $\left(R^{2}\right)$ and RMSE of the evaluated drying kinetics models.

\begin{tabular}{|c|c|c|c|c|c|}
\hline \multirow[t]{4}{*}{ Model } & \multirow[t]{4}{*}{ Parameter } & \multicolumn{4}{|c|}{ Temperature } \\
\hline & & \multicolumn{2}{|c|}{$60^{\circ} \mathrm{C}$} & \multicolumn{2}{|c|}{$75^{\circ} \mathrm{C}$} \\
\hline & & \multicolumn{2}{|c|}{ Drying air velocity } & \multicolumn{2}{|c|}{ Drying air velocity } \\
\hline & & $1.5 \mathrm{~m} \mathrm{~s}^{-1}$ & $3.0 \mathrm{~m} \mathrm{~s}^{-1}$ & $1.5 \mathrm{~m} \mathrm{~s}^{-1}$ & $3.0 \mathrm{~m} \mathrm{~s}^{-1}$ \\
\hline \multirow[t]{4}{*}{ Henderson and Pabis } & $k\left(\min ^{-1}\right)$ & 0.0138 & 0.0142 & 0.0223 & 0.0240 \\
\hline & $C(-)$ & 1.0501 & 1.0501 & 1.0442 & 1.0399 \\
\hline & $\mathrm{R}^{2}$ & 0.9919 & 0.9906 & 0.9870 & 0.9886 \\
\hline & RMSE & 0.0266 & 0.0289 & 0.0360 & 0.0333 \\
\hline \multirow[t]{3}{*}{ Newton } & $\mathrm{k}\left(\mathrm{min}^{-1}\right)$ & 0.0132 & 0.0136 & 0.0215 & 0.0232 \\
\hline & $\mathrm{R}^{2}$ & 0.9895 & 0.9882 & 0.9850 & 0.9870 \\
\hline & RMSE & 0.0302 & 0.0324 & 0.0386 & 0.0356 \\
\hline \multirow[t]{4}{*}{ Page } & $\mathrm{k}\left(\mathrm{min}^{-1}\right)$ & 0.0047 & 0.0046 & 0.0067 & 0.0080 \\
\hline & $\mathrm{n}(-)$ & 1.2255 & 1.2381 & 1.2843 & 1.2674 \\
\hline & $\mathrm{R}^{2}$ & 0.9987 & 0.9984 & 0.9974 & 0.9975 \\
\hline & RMSE & 0.0108 & 0.0121 & 0.0162 & 0.0156 \\
\hline \multirow[t]{3}{*}{ Fick } & $D\left(m^{2} \min ^{-1}\right)$ & $4.63 \times 10^{-8}$ & $4.78 \times 10^{-8}$ & $7.38 \times 10^{-8}$ & $7.98 \times 10^{-8}$ \\
\hline & $\mathrm{R}^{2}$ & 0.9807 & 0.9791 & 0.9743 & 0.9769 \\
\hline & RMSE & 0.0410 & 0.0431 & 0.0507 & 0.0475 \\
\hline
\end{tabular}

air temperature had a greater influence on water removal from the interior to surface of the product.

\section{CONCLUSION}

The equilibrium moisture content decreased with the increase in temperature for the same water activity values. The temperature increase caused a decrease in the monolayer content for the BET and GAB models, where that which presented the best fit was more appropriate to describe the adsorption behavior of the green pepper at the conditions studied. In the drying process the air temperature had a greater influence on drying time of the green pepper, while velocity was the variable of least influence on the process. The drying models evaluated showed satisfactory adjustment in all studied drying conditions, where the Page model was selected as that best describing the thin-layer drying kinetics of green peppers. The increase in temperature caused an increase in the effective diffusion coefficient, while the increase in drying air velocity practically did not change water removal from the inside to the surface of the food.

\section{Author's contributions}

G.R.F.G. and O.R.R.G. conducted experiment, analyzed data and wrote the manuscript. R.C.I.F. was the project leader, designed the study and was involved in manuscript preparation. R.C.F.B. was involved in manuscript preparation and analysis data. All authors read and approved the manuscript.

\section{REFERENCES}

Akpinar, E. K. 2006. Determination of suitable thin layer drying curve model for some vegetables and fruits. J. Food Eng. 73: 75-84.
Andrade, P. R. D., M. R. Lemus and C. C. Rérez. 2011. Models of sorption isotherms for food: Use and limitations. Vitae. 18: 325-334.

AOAC. 2016. Oficial Methods of Analysis. $20^{\text {th }}$ ed. Association of Official Analytical Chemists, Arlington, VA.

Arévalo-Pinedo, A., A. D. Giraldo-Zuñiga, F. L. Santos, Z. D. S. Arévalo and R. P. Arévalo. 2004. Sorption isotherms experimental data and mathematical models for murici pulp (Byrsonima sericea). Proceedings of the $14^{\text {th }}$ International Drying Symposium, São Paulo: UNICAMP, p. 634-639.

Arslan, D. and M. M. Özcan. 2011. Dehydration of red bell-pepper (Capsicum annuum L.): Change in drying behavior, colour and antioxidant content. Food Bioprod. Process. 89: 504-513.

Arslan, N. and H. Togrul. 2005. Modeling of water sorption isotherms of macaroni stored in a chamber under controlled humidity and thermodynamic approach. J. Food Eng. 69: 133-145.

Blahovec, J. 2004. Sorption isotherms in materials of biological origin mathematical and physical approach. J. Food Eng. 65: 489-495.

Comunian, T. A., E. S. Monterrey-Quintero, M. Thomazini, J. C. C. Balieiro, P. Piccone, P. Pittia and C. S. Favaro-Trindade. 2011. Assessment of production efficiency, physicochemical properties and storage stability of spray-dried chlorophyllide, a natural food colourant, using gum Arabic, maltodextrin and soy protein isolate-based Carrier systems. Int. J. Food Sci. Tech. 46: $1259-1265$.

Doymaz, I. 2008. Convective drying kinetics of strawberry. Chem. Eng. Process. 47: 914-919.

Ertekin, C. and M. Z. Firat. 2017. A comprehensive review of thin layer drying models used in agricultural products. Crit. Rev. Food Sci. Nut. 57: 701-717.

Figueira, G. M., K. J. Park, F. P. R. Brod and S. L. Honório. 2004 Evaluation of desorption isotherms, drying rates and inulin concentration of chicory roots (Cichoriou mintybus L.) with and without enzymatic inactivation. J. Food Eng. 63: 273-280.

Giraldo-Zuñiga, A. D., A. Arévalo Pinedo, R. M. Rodrigues, C. S. S. Lima and A. C. Feitosa. 2006. Kinetic drying experimental data and mathematical model for jackfruit (Artocarpus integrifolia) slices. Cienc. Tecnol. Aliment. 5: 89-92.

Goula, A. M., T. D. Karapantsios, D. S. Achilias and K. G. Adamopoulos. 2008. Water sorption isotherms and glass transition temperature of spray dried tomato pulp. J. Food Eng. 85: 73-83.

Emir. J. Food Agric • Vol $30 \bullet$ Issue 2 • 2018 
Greenspan, L. 1977. Humidity fixed points of binary saturated aqueous solutions. J. Res. Nbs. A. Phys. Ch. 81A: 89-96.

Krokida, M. K., V. T. Karathanos, Z. B. Maroulis and D. MarinosKouris. 2003. Drying kinetics of some vegetables. J. Food Eng. 59: 391-403.

Kurozawa, L. E., R. A. Oliveira, M. D. Hubinger and J. K. Park. 2015. Thermodynamic properties of water desorption of papaya. J. Food Process. Pres. 39: 2412-2420.

Palipane, K. B. and R. H. Driscoll. 1993. Moisture sorption characteristics of in-shell macadamia nuts. J. Food Eng. 18: 63-76.

Pavan, M. A., S. J. Schmidt and H. Feng. 2012. Water sorption behavior and thermal analysis of freeze-dried, Refractance Window-dried and hot-air dried açaí (Euterpe oleracea Martius) juice. LWT Food Sci. Technol. 48: 75-81.

Perdomo, J., A. Cova, A. J. Sandoval, L. Garcia, E. Laredo and A. J. Müller. 2009. Glass transition temperatures and water sorption isotherms of cassava starch. Carbohyd. Polym. 76: 305-313.

Santos, C. T., R. C. F. Bonomo, M. A. Chaves, R. C. I. Fontan and P. Bonomo. 2010. Kinetic and modeling of carambola drying
(Averrhoa carambola L.) in tray dryer. Acta Sci. Technol. 32: 309-313.

Singh, R., S. K. Giri and N. Kotwaliwale. 2014. Shelf-life enhancement of green bell pepper (Capsicum annuum L.) under active modified atmosphere storage. Food Packag. Shelf Life. 1: 101-112.

Spiess, W. E. L. and W. R. Wolf. 1993. The results of the COST 90 project on water activity. In: Jowitt, R., F. Escher., B. Hallstrom., H. Meffert., W. E. L. Spiess and G. Vos (Eds.), Physical Properties of Foods, Applied Science Publishers, London , p. 65-91.

Vega, A., P. Fito, A. Andrés's and R. Lemus. 2007. Mathematical modeling of hot-air drying kinetics of red bell pepper (var. Lamuyo). J. Food Eng. 79: 1460-1466.

Vega-Gálvez, A., R. Lemus-Mondaca., C. Bilbao-Sáinz., F. Yagnam and A. Rojas. 2008. Mass transfer kinetics during convective drying of red pepper var. Hungarian (Capsicum annuum L.): mathematical modeling and evaluation of kinetic parameters. J. Food Process Eng. 31: 120-137.

Yan, Z., M. J. Souza-Gallagher and F. A. R. Oliveira. 2008. Sorption isotherms and moisture sorption hysteresis of intermediate moisture content banana. J. Food Eng. 86: 342-348. 